\title{
Desiccation-Induced Volumetric Shrinkage Characteristics of Highly Expansive Tropical Black Clay Treated with Groundnut Shell Ash for Barrier Consideration
}

\author{
George Moses ${ }^{1} \quad$ Roland K. Etim ${ }^{2 *} \quad$ John E. Sani ${ }^{1} \quad$ Michael Nwude $^{3}$ \\ 1.Department of Civil Engineering, Nigerian Defence Academy, Kaduna, Nigeria \\ 2.Department of Civil Engineering, Akwa Ibom State University, Ikot Akpaden, Nigeria \\ 3.Department of Water Resources Engineering, National Water Resources Institute, Kaduna, Nigeria
}

\begin{abstract}
Contamination of underground water as a result of excessive crack on clay liner material is a prevalent phenomenon in an engineered landfill. Volumetric shrinkage strain (VSS) is one of the veritable properties considered for selection of materials suitable for liners and cover in waste containment systems. Material devoid of excessive shrinkage and cracking during climate change could possibly make a better barrier material that will eventually limit or control infiltration of leachate in an engineered landfill. Hence, to obtain a clay liner and covers system that are safe and robust, stabilization of such soil (expansive clay soils) becomes imperative. In order to stabilize or reduce excessive cracking and shrinkage of this soil, earlier researchers have employed cement, chemicals, and fibers. However, in recent times, the ill effects of these stabilizers on the environment have been realized, and hence their replacement with sustainable materials that are mostly agro and or industry by-products is becoming necessary. Tropical dark grey clay treated with up to $8 \%$ Groundnut shell ash (GSA), was carried out. Specimen were compacted using British standard light (BSL) and British standard heavy (BSH) compactive efforts; at water contents between $2 \%$ dry and $4 \%$ wet of optimum. The compacted specimens were extruded and subjected to drying under laboratory conditions to evaluate its desiccation induced shrinkage and hence its suitability as a cover material in waste containment facilities. Results of this study show that changes in mass and volumetric shrinkage strain were large within the first five days of drying. Volumetric shrinkage strain increased with higher moulding water contents (MWC) and water contents relative to optimum (WRO). The effect of GSA treatment on VSS was not consistent from -2 to $+2 \%$ of optimum moisture content. For specimen prepared at $+4 \%$ of optimum moisture content, VSS decreased up to a threshold of $28 \%$ at $6 \%$ GSA and $30 \%$ at $4 \%$ GSA for BSH and BSL compactive effort, respectively. Generally, lower compactive effort (BSL) with higher moulding water content and lower dry density produced higher VSS. A regression function was developed from the data to estimate VSS given the compaction water content relative to optimum (WRO), groundnut shell ash content (GSA), plasticity index (PI), percentage fine content (PF) and compactive effort (CE). Compaction water content relative to optimum significantly correlated with VSS, thus should be strictly regulated during field compaction to realize a durable hydraulic barrier.
\end{abstract}

Keywords: Atterberg limit, compaction, desiccation, expansive soil, groundnut shell ash, statistical analysis DOI: $10.7176 / \mathrm{CER} / 11-8-06$

Publication date:September $30^{\text {th }} 2019$

\section{Introduction}

The importance of desiccation-induced shrinkage study on hydraulic barrier material is very significant in the structure of liner frameworks. Undue volume changes in varying extraordinary climate conditions (from dry to wet seasons) result to cracks being formed at their surface and subsequently spread deeper inside their matrix. This could result in the numerical increment in of hydraulic conductivity values. An increase in the hydraulic conductivity value past the reasonable most extreme farthest point of $10^{-9} \mathrm{~m} / \mathrm{s}$ prompts permeation of fluid through the cracks. Failure of the liner framework ends up unavoidable as the quality of the crack soils diminishes whilst there are expanded progression of contaminants through its crevices into the ground. Clay liners are constantly exposed to drying amid construction and post construction but splitting and cracks becomes evident because shrinkage is a potential issue. Daniel and Benson (1990) suggested a most extreme volumetric shrinkage strain of $4 \%$ for any material to be reasonable for the development of a hydraulic barrier. The structure of the liner will of course depends on accomplishing a material with the ideal hydraulic conductivity. Be that as it may, the decrease in hydraulic conductivity is frequently linked by an increase in volume due to the vulnerability of clay to drying shrinkage. The impact of this on the properties and the structure of a compacted barrier is that it could change with time thus bringing about a decrease of the viability of the barrier. Also, the deterioration of barrier can be as a result of volumetric changes foisted by climatic wet-dry or volumetric changes connected with the interactions of clay structure with leachate.

The environmental suitability, feasibility, and performance of the beneficial reuse of industrial and agricultural waste material are increasingly being investigated by researchers. Different stabilization agents 
(asphalt, lime, fly ash, aqueous polymers, bagasse ash and blast furnace slag) have been used to reduce shrinkage, cracking and even dust generation especially in clayey barrier soils under synergistic environmental stresses. Blast furnace slag, bagasse ash, and fly ash were shown to improve desiccative properties of lateritic soils as clay liners for up to 15\% treatment (Osinubi et al., 2009; Osinubi and Eberemu 2010). Researchers have also shown that some of the soil properties (soil index properties (workability) and compaction characteristics) of fine grained soils can be enhanced by the addition of pozzolanic fly ash (Nicholson and Kashyap 1993; Coka 2001; Pandian and Krishma 2003; Trzebiatowski et al., 2004; Terzi 2009). Furthermore, quite a number of studies on the use of compacted fine grain soil as liners and cover in waste containment application are reported (Liman, 2009; Osinubi and Nwaiwu, 2005, 2005a,b; Osinubi and Eberemu, 2006; Osinubi and Eberemu, 2009b; Osinubi and Amadi, 2006; Osinubi and Amadi, 2009, 2010; Jayanthi et al., 2017).

Large quantities of waste materials from mineral, agricultural, domestic and industrial sources are generated daily, and the safe disposal of these wastes has increasingly become a major concern around the world (US. EPA, 2009). Consequently, safeguarding the environment from pollutants arising from wastes generated by man-made activities and disposal systems in less developed countries is at present a subject of growing concern. This is because of its negative impact on the environment, particularly on soil and groundwater which ultimately affects the health of the populace (Eberemu and Osinubi 2010; Eberemu et al., 2010; Mitchel 2008). Groundnut shell is an agricultural waste obtained from milling of groundnut. Nigeria contributes about 7 percent of world groundnut production which makes Nigeria the 3rd largest producer of groundnut in the world thus account for large groundnut shell wastes. In some places they are dumped in open land fill. This litters the environment. Meanwhile, the ash from groundnut shell has been categorized under pozzolana (Alabadan et.al, 2006), with about 8.66\% Calcium Oxide (CaO), 1.93\% Iron Oxide $\left(\mathrm{Fe}_{2} \mathrm{O}_{3}\right), 6.12 \%$ Magnesium Oxide $(\mathrm{MgO}), 15.92 \%$ Silicon Oxide $\left(\mathrm{SiO}_{2}\right)$, and $6.73 \%$ Aluminum Oxide $\left(\mathrm{Al}_{2} \mathrm{O}_{3}\right)$. The utilization of this pozzolana as a replacement for traditional stabilizers will go a long way in actualizing the dreams of most developing countries of scouting for cheap and readily available construction materials. Groundnut shell ash as a partial replacement material for cement in concrete was achieved with a measure of success (Alabadan et al., 2005). Agricultural waste is increasingly becoming a focus for researchers because of its enhanced pozzzolanic capabilities when oxidized by burning.

Tropical clayey soils treated with GSA for use as a hydraulic barrier material in waste containment systems has the potential to using up some of the groundnut shell generated; this may be particularly advantageous to land fill operations in areas where groundnut production is high. This paper considers the results of the study of the physical properties of a tropical clayey soil treated with GSA for potential usage as barriers in waste containment application. The study is focused on the desiccation effect of compacted tropical black clay treated with groundnut shell ash with possible effect of ameliorating cracks as well as reducing shrinkage characteristics..

\section{Material and Method}

\subsection{Material}

Soil: The black cotton soil used in this study was collected from a study burrow area located in Adamawa state Numan Local Government (latitude $9^{\circ} 27^{\prime} 49.46^{\prime} \mathrm{N}$ and longitude $12^{\circ} 01^{\prime}$ '50.23” E) Adamawa State in Nigeria by using the method of disturb sampling at depth ranging from 1.0 to $1.5 \mathrm{~m}$. The dominant clay mineral from the $\mathrm{X}$ ray diffraction studies on the soil from the burrow area is montmorillonite. It is dark grey in colour and classified as A-7-6 (26) according to AASHTO soil classification system (AASHTO 1986) and CH according to the Unified Soil Classification System (ASTM 1992).

Groundnut shell ash (GSA): Groundnut shell was packed in heaps and burnt to ashes by open air burning, allowed to cool and then carefully sieved through $0.075 \mathrm{~mm}$ aperture (BS No. 200) sieve to get rid of undesirable materials. The sieved specimen was preserved in an airtight polythene bag to prevent pre-hydration and kept in the laboratory to be used for the test. The GSA was admixed with the soil in stepped increase of $2 \%$ from $0 \%$ to $8 \%$ by dry weight of soil to establish five different soil - GSA mixtures. A sample of the soil and ash was analyzed for its oxide composition. The oxide composition of black cotton soil (BCS) and GSA (Table 1) was done using the Atomic Absorption Spectrophotometer (AAS) of the Nigerian Geological Survey Agency Kaduna, Nigeria.

\subsection{Methods}

Index Properties: Laboratory tests were performed to determine the index properties of the natural soil and soil mixtures in accordance with British Standards BS 1377 (1990) and BS 1924 (1990), respectively.

Compaction: Two compactive effort namely standard Proctor or British Standard Light (BSL) and modified Proctor or British Standard Heavy (BSH) were used in tests involving the moisture density relationship and volumetric shrinkage, simulating the variation in compaction energies that might occur in the field. The air-dried soil samples passed through the BS sieve with a $4.76 \mathrm{~mm}$ aperture were mixed with $0,2,4,6$ and $8 \%$ groundnut shell ash (GSA) by weight of dry soil were used. Proctor or British Standard Light (BSL) and modified Proctor or British Standard Heavy (BSH) compactive efforts were carried in accordance with British Standard BS 1377(1990). Volumetric shrinkage: Drying: The volumetric shrinkage upon drying was measured by extruding the cylindrical 
specimens, which were compacted using the BSL and BSH energy levels. The air dried soil - GSA mixtures were compacted at at four different moulding water contents i.e., $2 \%$ dry of optimum (-2\%), optimum moisture content $(0 \%), 2 \%$ wet of optimum $(+2 \%)$ and $4 \%$ wet of optimum $(+4 \%)$, from the compaction moulds. The extruded cylindrical specimens were placed serially on a laboratory bench and allowed to dry at a uniform temperature of $25 \pm 2^{\circ} \mathrm{C}$ for 30 days to dry naturally because natural drying is considered as a simulation of field conditions. Dimensions (three each) of the diameters and heights for each specimen were measured at marked interval of $120^{\circ}$ of the sample at five days interval with the aid of a digital vernier caliper accurate to $0.01 \mathrm{~mm}$. The mass of the sample was also measured at this interval with a digital weighing balance. The average diameters and heights were used to compute the volumetric shrinkage strain using the following expression:

$$
V S S=\frac{V_{o}-V_{f}}{V_{o}}
$$

where; VSS is volumetric shrinkage strain, $V_{o}$ is original volume of moist compacted cylindrical specimen and $V_{f}$ is the final volume of dry compacted cylindrical specimen.

\section{Results and Discussion}

\subsection{Index Properties}

The results of the physical properties of the natural soil used in this study are summarized in Table 2 . The soil is classified under the A-7-6 (26) subgroup of the AASHTO classification system (AASHTO, 1986) or CH in the unified Soil Classification System (USCS) (ASTM, 1992). The liquid limit and plasticity index values of 70.63 and $31 \%$, respectively, indicate suggest signify that the soil is highly plastic. Accordingly, the soil falls below the standard recommended for most geotechnical construction works (Butcher and Sailie, 1984).

Table 1. Oxide composition of black cotton soil (BCS) and groundnut shell ash (GSA)

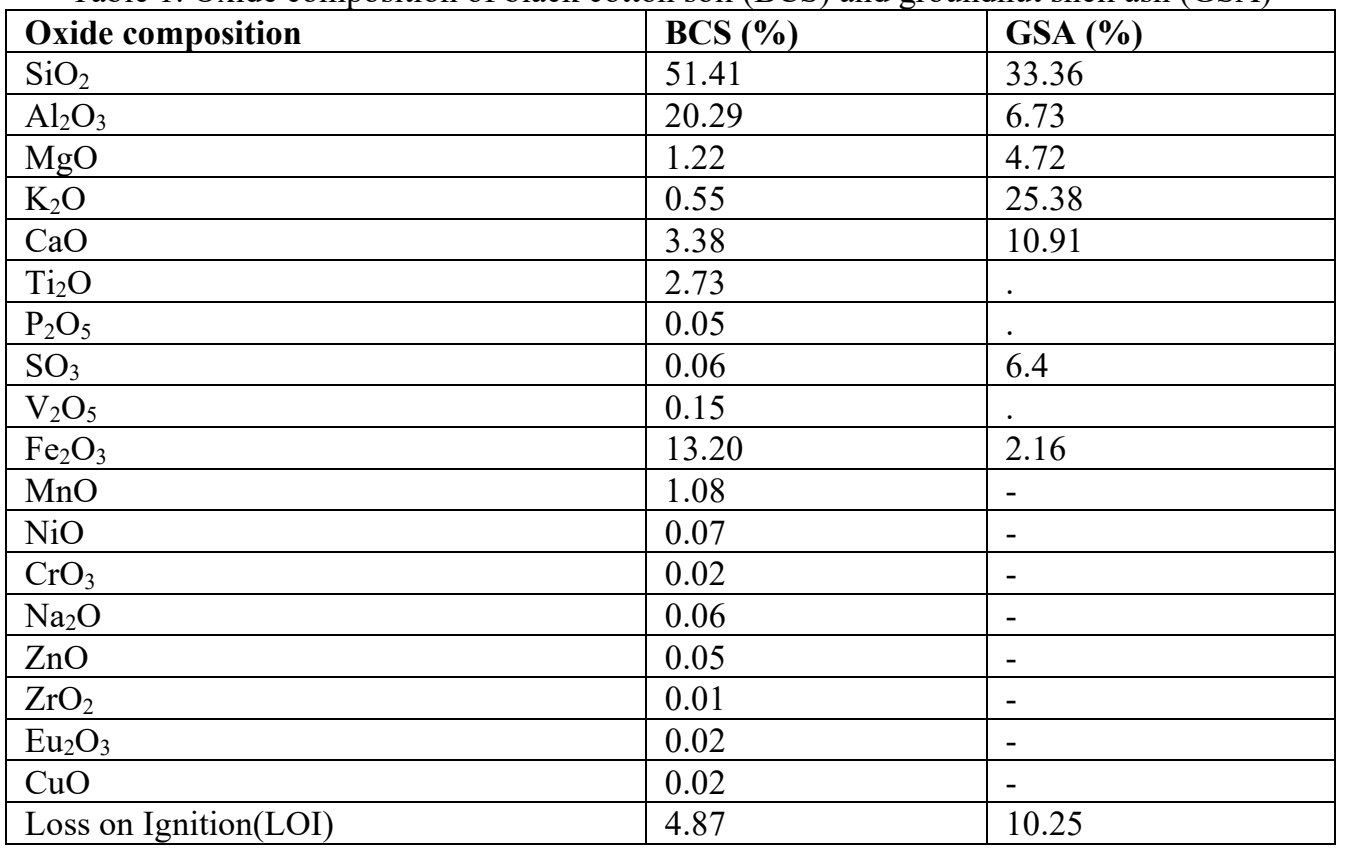


Table 2. Results of tests on natural black cotton soil

\begin{tabular}{|c|c|}
\hline Property & Quantity \\
\hline Percentage passing BS No 200 sieve (\%) & 75 \\
\hline Natural moisture content (\%) & 14.5 \\
\hline Liquid limit (\%) & 70.63 \\
\hline Plastic limit (\%) & 32 \\
\hline Plasticity index (\%) & 31 \\
\hline Linear shrinkage (\%) & 21 \\
\hline Specific gravity & 2.34 \\
\hline Free swell & 90 \\
\hline AASHTO classification & A-7-6 (26) \\
\hline UCSC & $\mathrm{CH}$ \\
\hline NBRRI classification & High swell potential \\
\hline Colour & Dark grey \\
\hline Dominant clay mineral & montmorillonite \\
\hline \multicolumn{2}{|c|}{ Maximum dry density $\mathrm{Mg} / \mathrm{m}^{3}$} \\
\hline British Standard light (standard proctor) & 1.45 \\
\hline British Standard heavy (modified proctor) & 1.67 \\
\hline \multicolumn{2}{|c|}{ Optimum moisture content (\%) } \\
\hline British Standard light (standard proctor) & 17 \\
\hline British Standard heavy (modified proctor) & 15 \\
\hline
\end{tabular}

\subsection{Atterberg limits}

The results show improved index properties with a decrease in liquid limit (LL) up to a threshold of $6 \%$ GSA content, an increase in plastic limits (PL) with a resulting decrease in plasticity index (PI) to a limit at $4 \%$ GSA content. These are due to physiochemical changes on the clay particles caused by cation exchange between the GSA and clay sized fractions. When treated with with up to $8 \% \mathrm{GSA}$, the liquid limit and plastic limit ranged from $51-63 \%$ and from $32-38 \%$, respectively, thus resulting in a decrease of plasticity index (PI) values from $31 \%$ at $0 \%$ GSA content to $16 \%$ at $4 \%$ GSA content. The linear shrinkage decreased with increase in the ash content for up to $4 \%$ treatment. Similar results indicative of enhanced index properties were obtained when fly ash (Coka 2011), rice husk ash (Eberemu, 2011) and iron ore tailing (Etim et al., 2014; Osinubi et al., 2015) was used. The Atterberg limits are indices of the quantity of clay sized particles and their mineralogical composition. Typically, higher liquid limits and plasticity indices values are linked with soils having a significant amount of clay particles or particles having higher surface activity. Also, lower hydraulic conductivities is associated with soils having higher liquid limits or plasticity indices (Benson et al., 1994). However, some researchers (Daniel, 1993; Rowe et al., 1995) suggested that materials with plasticity index (PI) $\geq 7 \%$ would be suitable for a hydraulic barrier. Therefore the different soil- GSA mixes employed in this study are suitable materials for hydraulic barriers.

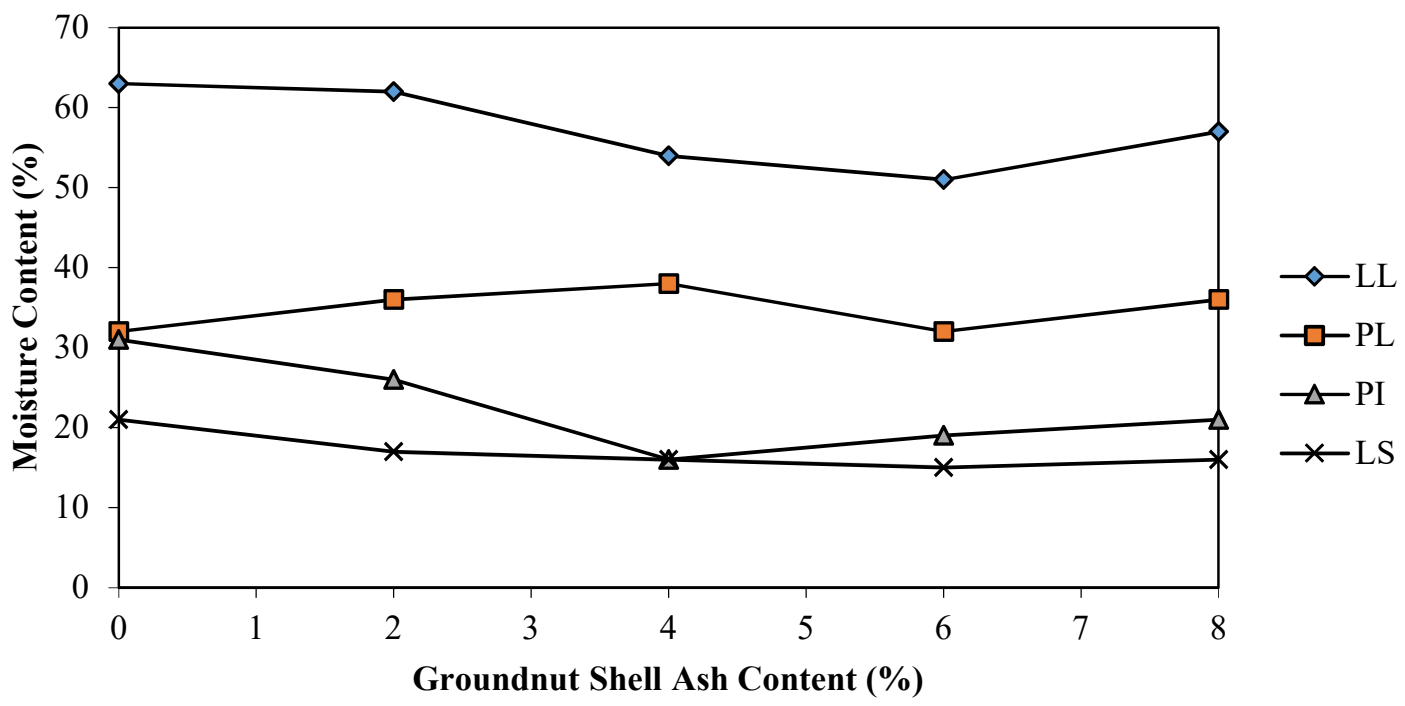

Figure1. Variation of Atterberg limits of soil with groundnut shell ash content 


\subsection{Compaction Characteristics}

The variation of the maximum dry density (MDD) of the black cotton soil with GSA content is shown in Fig.2. The MDD initially decreased on addition of GSA to a value of $1.32 \mathrm{Mg} / \mathrm{m}^{3}$ at $2 \%$ GSA content and afterward increased with increasing GSA content for the BSL energy level. The initial decrease in MDD is not unconnected with the initial simultaneous flocculation and agglomeration of clay particles caused by cation exchange leading to increase in volume and decrease in dry density. Also, this could be due to the comparatively low specific gravity value of 2.15 of the GSA compared to that of the soil which is 2.37. This is in agreement with the works of Ferguson (1993), Nicholson and Kashyap (1993) as well as Osinubi et al. (2007). However, as the amount of GSA increased, the MDD equally increased which may be due to the increased amounts of more pozzolanic material in the soil matrix. For specimen compacted using BSH, the MDD was unaffected up to $2 \%$ GSA as its values was observed to be constant at $1.67 \mathrm{Mg} / \mathrm{m}^{3}$ within 0 to $2 \%$ GSA content range. Beyond this range, the MDD slightly increased to $1.68 \mathrm{Mg} / \mathrm{m}^{3}$ and then subsequently decreased. The reason for the slight increase as well as decrease in MDD with increasing GSA content is same as explained for the case of BSL. Regardless of the trend as observed for both BSL and BSH compactive effort, it can be observed that higher compactive effort produced higher MDD while lower compactive effort produced lower MDD i.e. the MDD increased with higher compactive effort for each of the specimens.

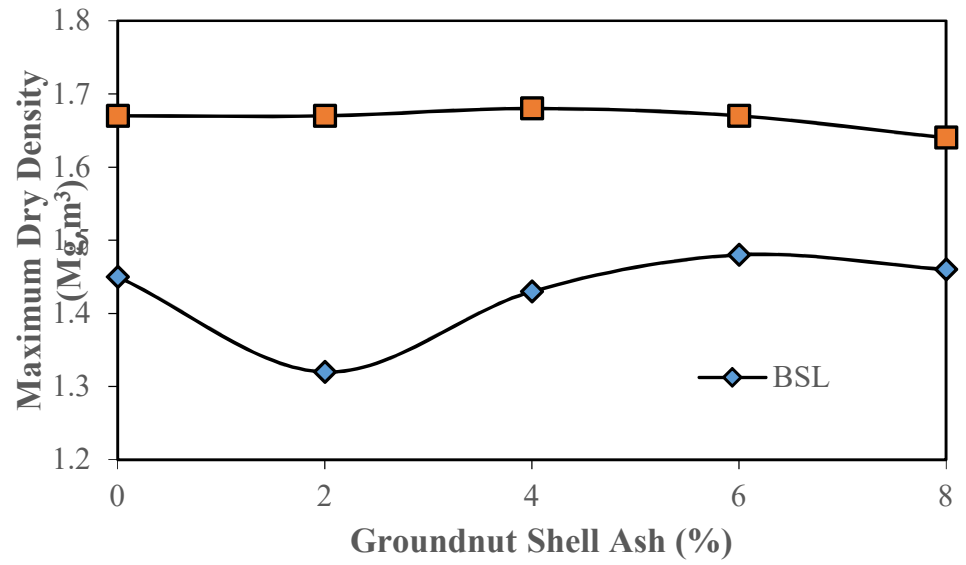

Figure 2. Variation of maximum dry density of black cotton soil with groundnut shell ash content

The effect of groundnut shell ash (GSA) content on the optimum moisture content (OMC) of the black cotton soil at BSL and BSH respectively is shown in Figure 3. Generally, the OMC increased with increasing GSA treatment from $17 \%$ to $22 \%$ and from $15 \%$ to $19 \%$ for both specimens compacted at BSL and BSH, respectively. The observed increase could be attributed to the increase in fine content follow-on from the addition of GSA with larger surface area that required more water for hydration. This finding is consistent with the works other researchers (Eberemu et al., 2011; Moses et al., 2016; Ijimdiya et al., 2012; Etim et al., 2017). The OMC also reduced with higher compactive effort for each of the specimens.

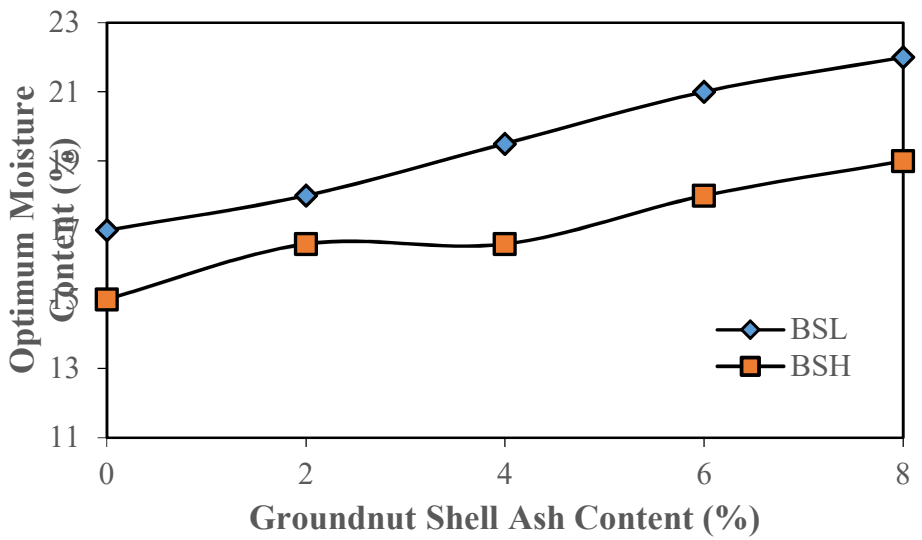

Figure 3. Variation of optimum moisture content of black cotton soil with groundnut shell ash

\subsection{Volumetric Shrinkage Strain}

The laboratory drying procedure is to simulate the slow rate of drying that occurs in the field, under a reasonable test time. The volumetric shrinkage strain was observed from changes that occurred during drying, moulding water content, water content relative to optimum and groundnut shell ash content and compactive effort. 


\subsubsection{Changes during drying}

The variation of cylindrical mass of specimens, prepared at the OMC for different compaction efforts and up to 8\% GSA, with drying period is shown in Figure 4.a-e, respectively. Generally, in all cases the changes or loss in mass was sharp within the first five days of drying as observed from the drop of the graph and subsequently became relatively constant until samples were completely dried. It could be that the mass stops changing when the cavity pressure has decayed to zero due to loss of moisture. After this, the volumetric shrinkage becomes constant. The findings observed in this study mirror those of the previous studies that have also examined the effect of drying period on the mass of specimen (Albrecht and Benson 2001; Osinubi and Eberemu 2010; Eberemu 2011; Moses et al., 2016). The changes in mass during drying were unaffected by the ground nut shell ash treatment and compactive effort, although specimens with higher compactive effort plotted above those with lower effort from the plots of changes in mass during drying which is due to the higher dry density generated by higher compactive effort. These results are consistent with those reported (Osinubi and Eberemu, 2010, Albrecht and Benson, 2001 and Moses et al., 2016).

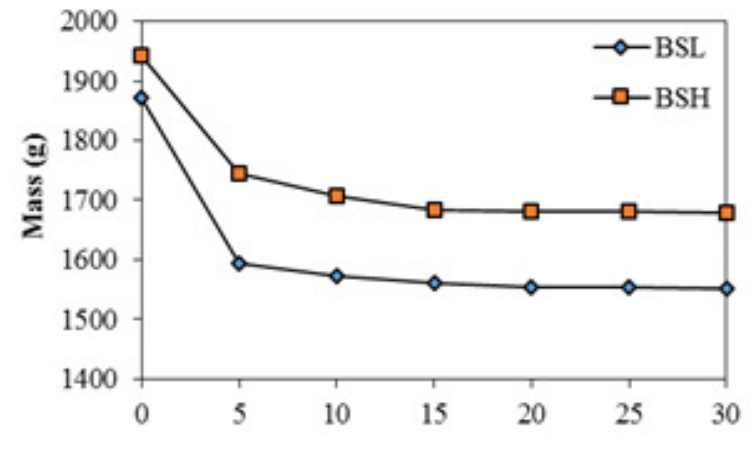

(a)

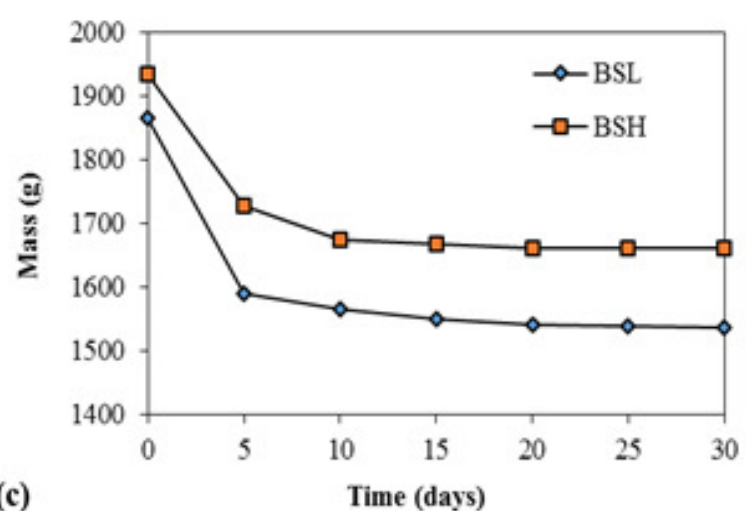

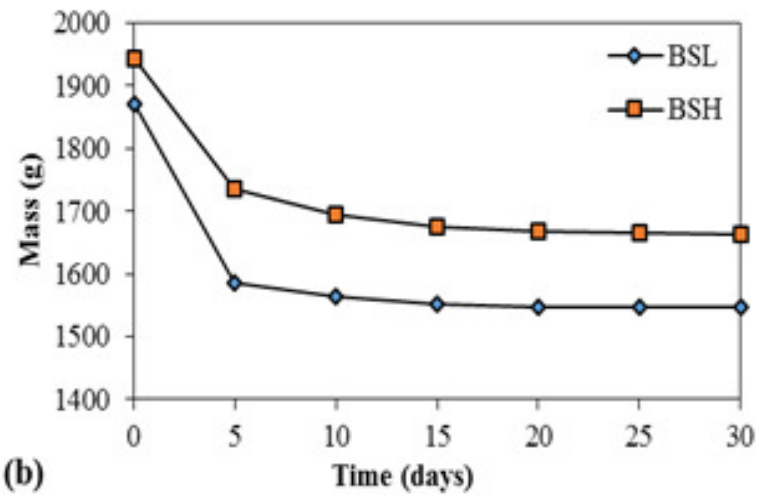

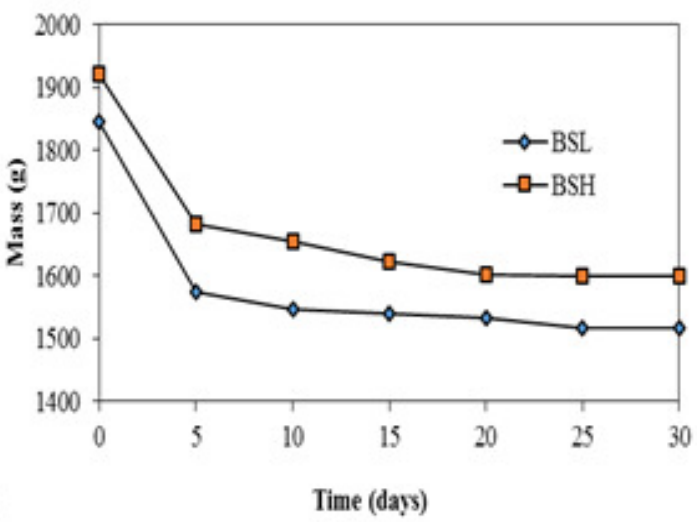

(e)

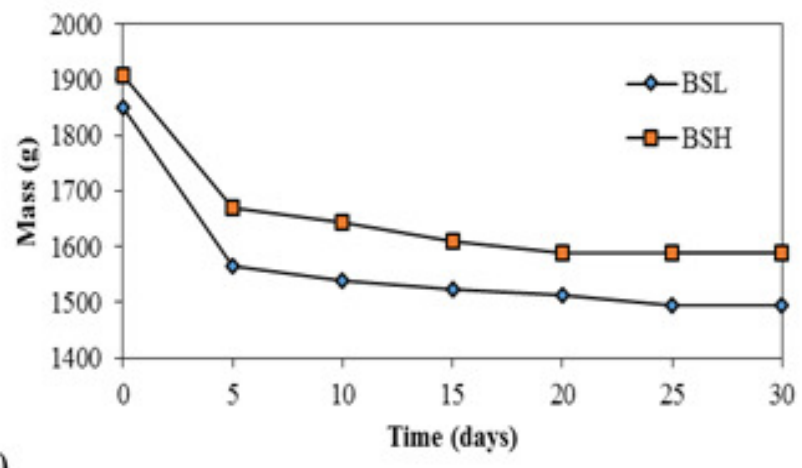

Figure 4: Variation of mass with time during volumetric shrinkage at the OMC for (a) the natural soil (b) 2\% GSA (c) 4\% GSA (d) 6\% GSA (e) $8 \%$ GSA

The results of volumetric shrinkage strain (VSS) with time at the OMC for the various compactive efforts with ground shell ash treatment up to $8 \%$ are shown in Figure 4. Results recorded show that the rates of change in volumetric shrinkage strain were generally sharp within the first five days of drying after which they reduced gradually and became relatively constant by the tenth-fifteenth day when the samples were fully dried for all the efforts used. It can be observed that these changes were affected by the compactive efforts. This translates to the 
fact that volumetric shrinkage strain values were higher at lower compactive efforts owing to the higher moulding water content contained at lower compactive efforts since volumetric shrinkage strain is proportional to moulding water content. This finding further confirms the association/correlation between volumetric shrinkage strain and compaction condition (Osinubi and Nwaiwu 2008). This result is also consistent with that reported (Albrecht and Benson, 2001, Das, 1998.). Taha and Taha (2011) confirms that most of the changes in soil structure or the total volume occur during the initial drying phase. Invariably, this implies that the decrease in the water content contained in a soil will results to a corresponding decrease in the volumetric shrinkage. Likewise, if soil density increases, the volumetric shrinkage decreases, which in turn causes cracks in the soil to decrease as well.
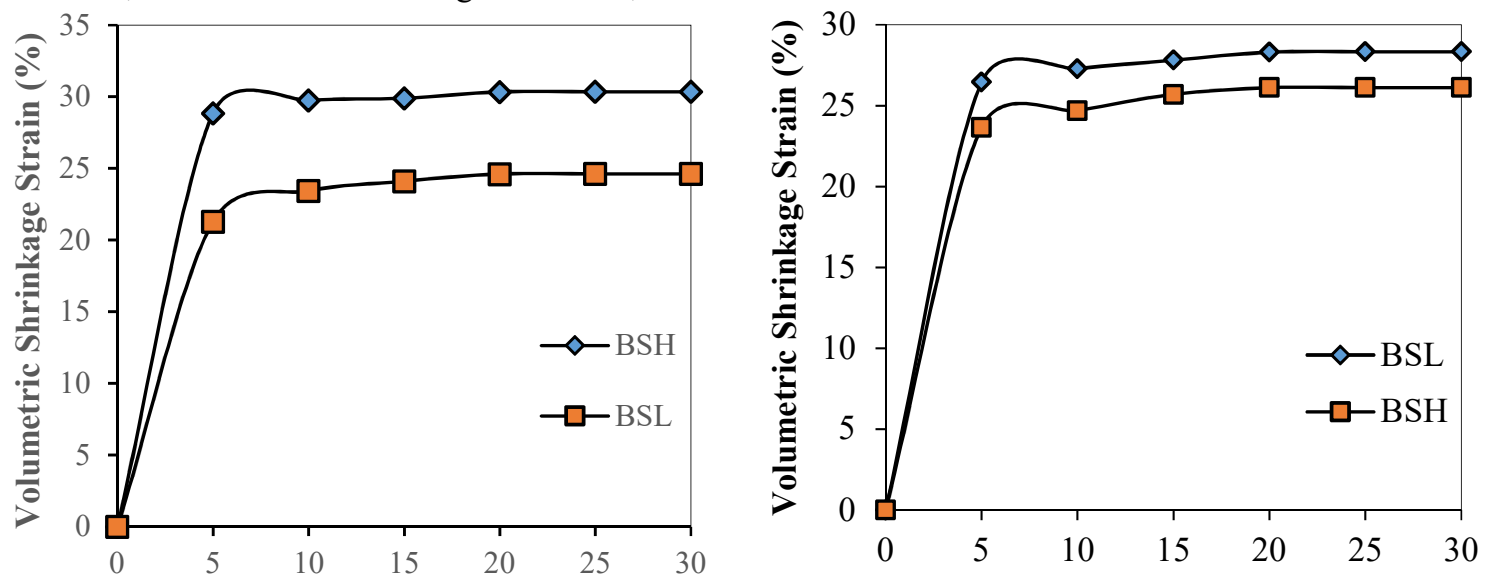

(a)

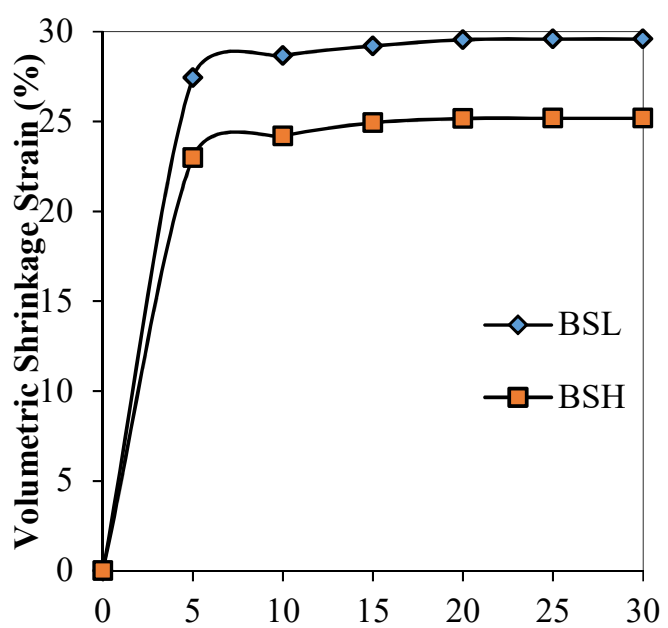

(c)
Time (days) (b)

Time (days)

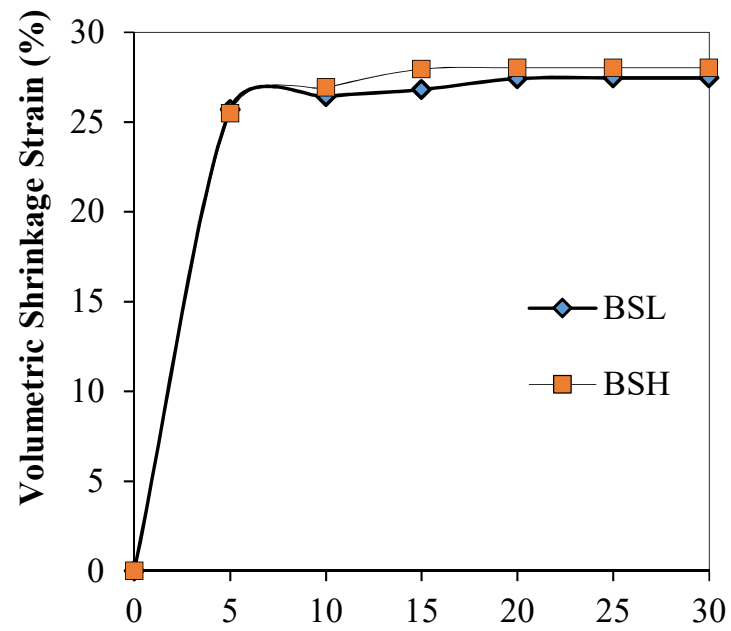

(d)

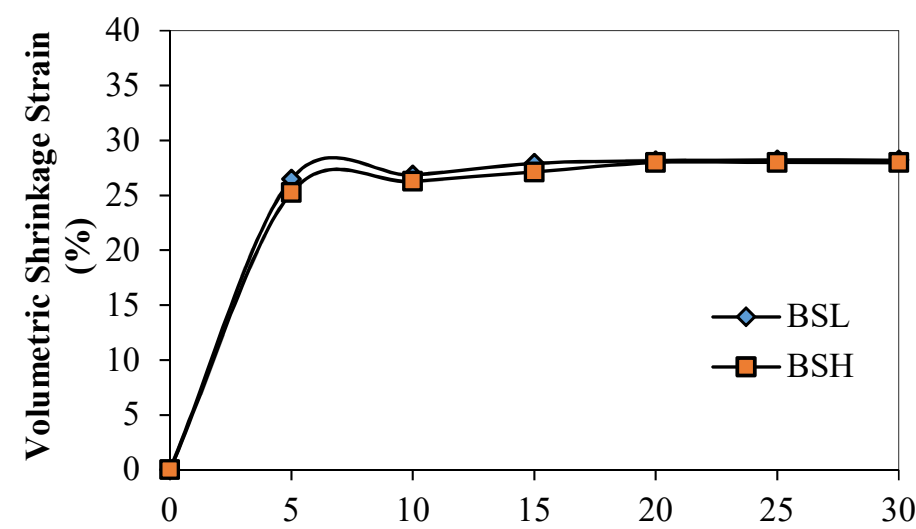

(e)

Time (days)

Figure 5: Variation of volumetric shrinkage strain with time at the OMC for (a) the natural soil (b) $2 \%$ GSA (c) $4 \%$ GSA (d) $6 \%$ GSA (e) $8 \%$ GSA 


\subsubsection{Effect of moulding water content}

The effect of moulding water content on the volumetric shrinkage strain is shown in Figure 6a-e. The result is that of a general increase in VSS with higher moulding waste content. In the course of drying, it was observed that the VSS was more obvious for specimens compacted at higher moulding. These results match those observed in earlier studies (Daniel and Wu (1993), Albrecht and Benson (2001), Osinubi and Eberemu 2010, Moses 2016)). The explanation to this according (Mitchell, 1976) is associated with the drying shrinkage in fine-grained soils which depends on particle movement due to pore water tension developed by capillary menisci, that if two samples of given clay are at the same initial water content but different fabrics, the one that is the more deflocculated and dispersed shrinks most; which is due to average smaller pore sizes, allowing greater capillary stresses and easier relative movement of particles and particle groups. Furthermore, samples compacted at higher moulding water contents, had more water in their void spaces that resulted in higher shrinkage on drying since volumetric shrinkage is proportional to the volume of water leaving the pore spaces. The VSS for the natural soil (0\% GSA) ranged from $27.62-32.5 \%$ for $15-21 \%$ moulding water content compacted at BSL. Likewise from $26.17-30.77 \%$ for $13-19 \%$ moulding water content compacted at BSH. Similarly, in all cases of GSA treatment and compactive efforts, compacted between -2 to +4 of the OMC the volumetric shrinkage follows similar trend with that of the untreated soil with a trend of increasing VSS with higher moulding water. These results are in consistent with those of Haines, (1923), who described the drying process of saturated soil as having two stages; the first stage occurring as water leaves the soil without the entry of air, since air is not entering the soil, the volume change is equal to the volume of water leaving the soil. The main volume change occurs during the first stage when water surrounding the individual soil particles to move closer as the water retreats. At some point, the particles contact each other, and the drying process slows as the soil structure begins to resist additional volume change. In the second stage, air enters the soil and replaces the water being removed because the particles are in contact. Little changes in soil structure or total volume occur during this stage. Regardless of the compactive efforts, the general trend shows that the entire volumetric shrinkage strain obtained for the various GSA treatment (ranging up to $8 \%$ content) exceeded the maximum permissible $4 \%$. This probably could be due to increased water as contained in the voids of compacted specimen leading to increased shrinkage. It could be that the range of GSA considered was not enough to stabilize the soil structure and therefore the $4 \%$ allowable VSS could not be achieved. From the foregoing, it can be said that higher GSA treatment beyond $8 \%$ would be needed to possibly stabilize the soil against desiccation shrinkage and conceivable cracks. Though there was decreased in VSS, its consideration in effective and robust hydraulic barrier construction may not be feasible because the allowable VSS was not achieved as earlier mentioned 


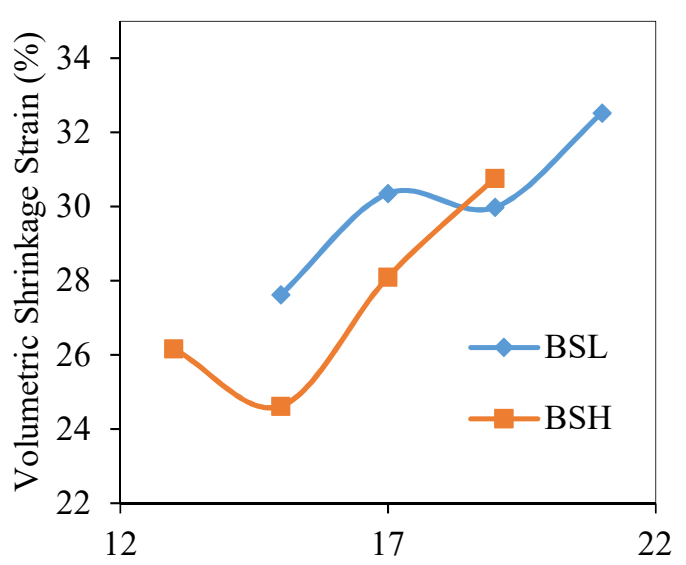

(a)

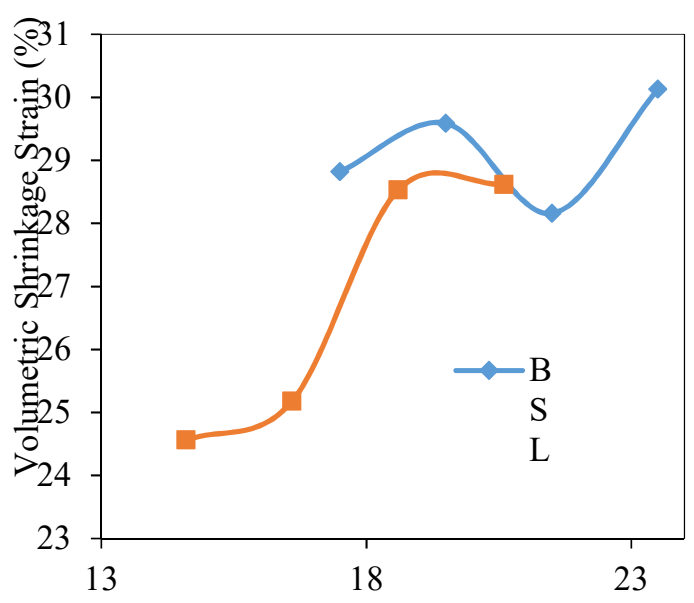

(c)

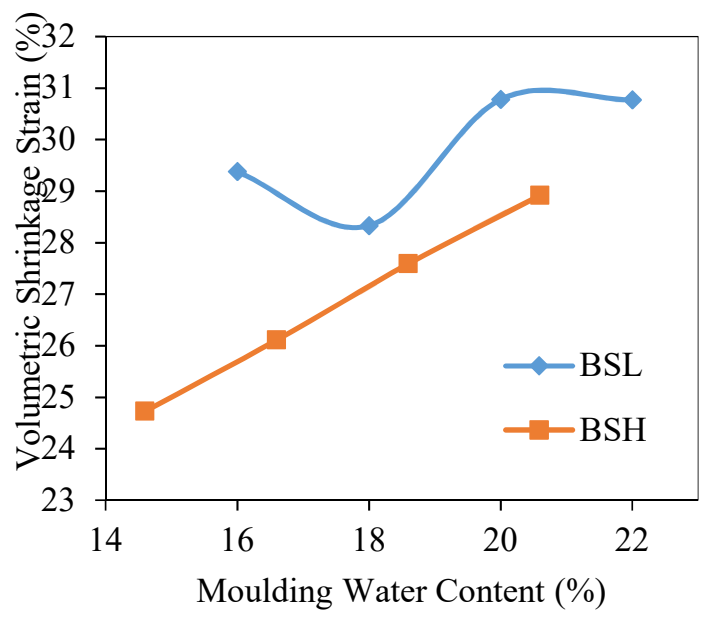

(b)

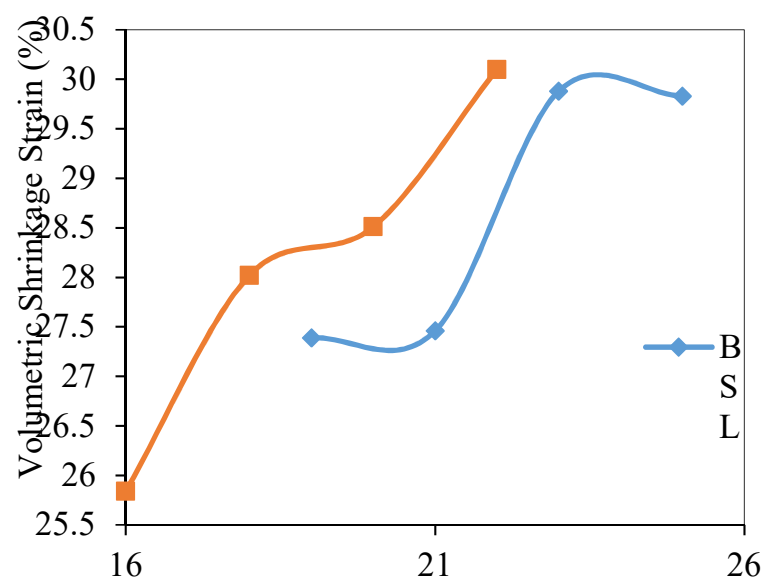

(d)

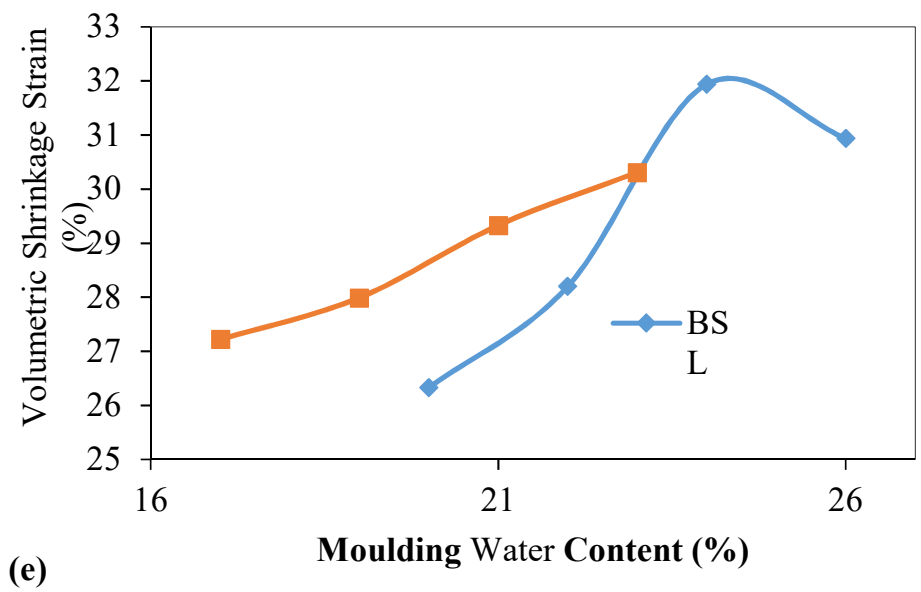

Figure 6. Variation of volumetric shrinkage strain versus moulding water content for (a) the natural soil (b) $2 \%$

$$
\text { GSA (c) } 4 \% \text { GSA (d) } 6 \% \text { GSA (e) } 8 \% \text { GSA }
$$

3.4.2 Effect of water content relative to optimum

The variation of volumetric shrinkage strain with water content relative to optimum is shown in Figure 7a-d. Generally, volumetric shrinkage strain increased with higher moulding water content relative to optimum for the natural soil compacted at moulding water contents in the range from -2 to $+4 \%$ of the $\mathrm{OMC}$, The maximum permissible VSS values of $4 \%$ were not obtained for all moulding water content relative to optimum and for both compaction efforts. Generally, specimens compacted at higher moulding water content shrank more during drying but with higher compactive energy, the relative effect of volumetric shrinkage strain is reduced. This result is consistent with those reported by Daniel and Wu (1993) as well as Albrecht and Benson (2001). 


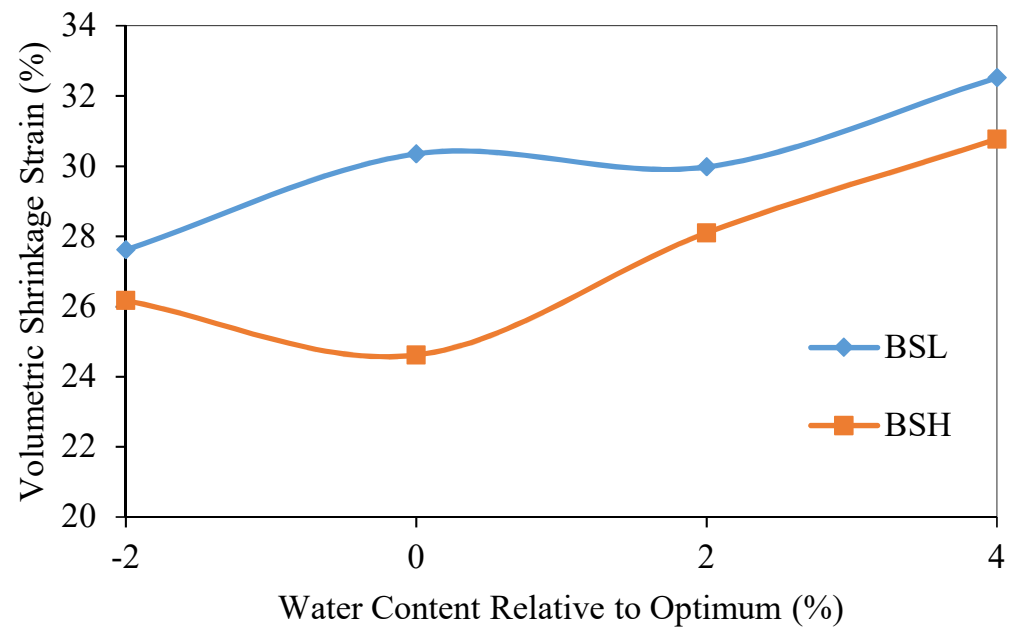

(a)

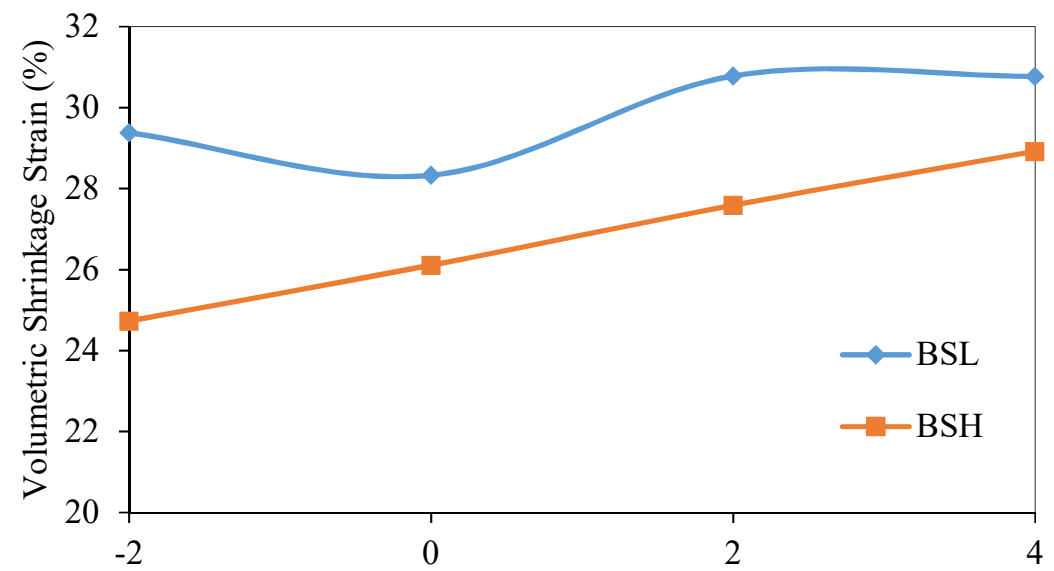

(b)

Water Content Relative to Optimum (\%)

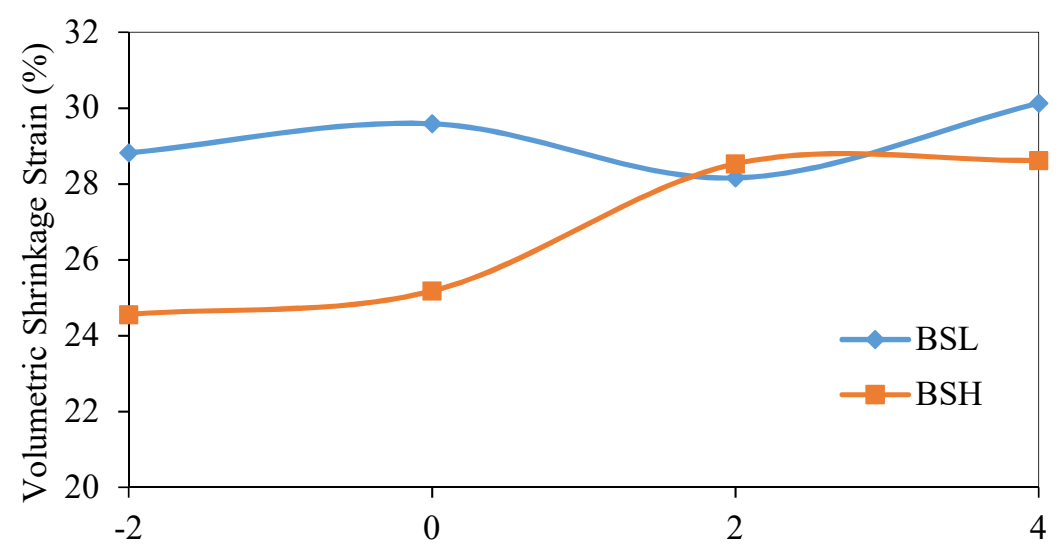

(c)

Water Content Relative to Optimum (\%) 


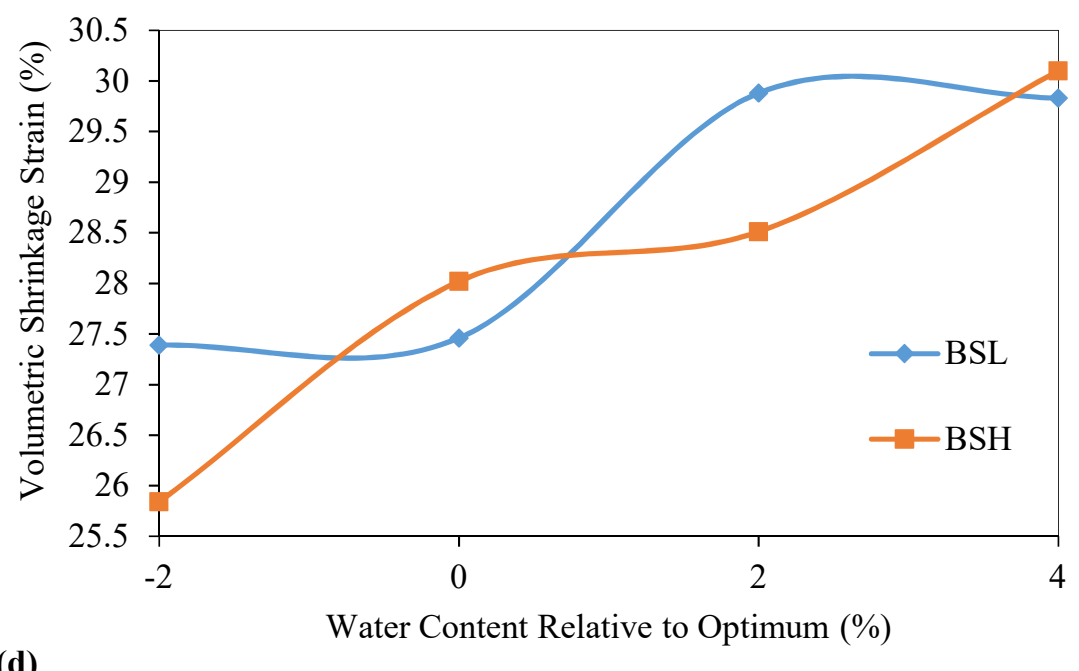

(d)

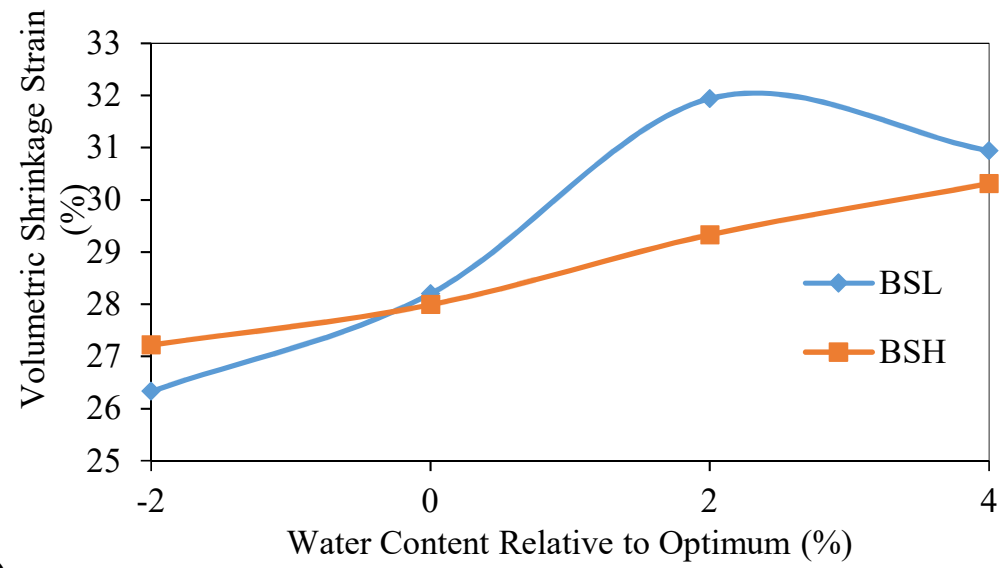

Figure 7: Variation of volumetric shrinkage strain with water content relative to optimum for (a) the natural soil (b) $2 \%$ GSA (c) $4 \%$ GSA (d) $6 \%$ GSA (e) $8 \%$ GSA

3.4.3 Effect of groundnut shell ash on the volumetric shrinkage

The variation of volumetric shrinkage strain with groundnut shell ash content at $-2,0,+2$ and $+4 \%$ OMC is shown in Fig 8a-d. The effect of higher GSA treatment on VSS was not consistent from -2 to $+2 \%$ of optimum moisture content. For specimen prepared at $+4 \%$ of optimum moisture content, VSS decreased up to a threshold of $28 \%$ at $6 \%$ GSA and $30 \%$ at $4 \%$ GSA for BSH and BSL compactive effort, respectively. Inasmuch as the permissible VSS was not achieved it is important to note that GSA contents and moulding water content should be strictly monitored. This is because higher GSA contents could results to more fines with larger surface areas being present in the soil-GSA mixture, which would require more water for hydration. The possible VSS behaviour could be due to the presence of multivalent cations $\left(\mathrm{Ca}^{2+}, \mathrm{Al}^{3+}, \mathrm{Fe}^{3+}, \mathrm{Mg}^{2+}\right.$, etc) in $\mathrm{GSA}$ that promote flocculation of clay particles through cation exchange. Thus, the surface area and water affinity of the samples decrease, which imply a reduction in swelling potential and increased shrinkage. This is consistent with the report of Eberemu (2011) who used rice husk ash. Regardless of the variation in GSA content, the VSS obtained for BSL were generally higher that those obtained for BSH. Furthermore, it is suspected that the percentage consideration of GSA did not reflect any drastic reduction in VSS. Therefore, it is expected that higher GSA content beyond $8 \%$ could probably lead to an effective reduction in VSS. 


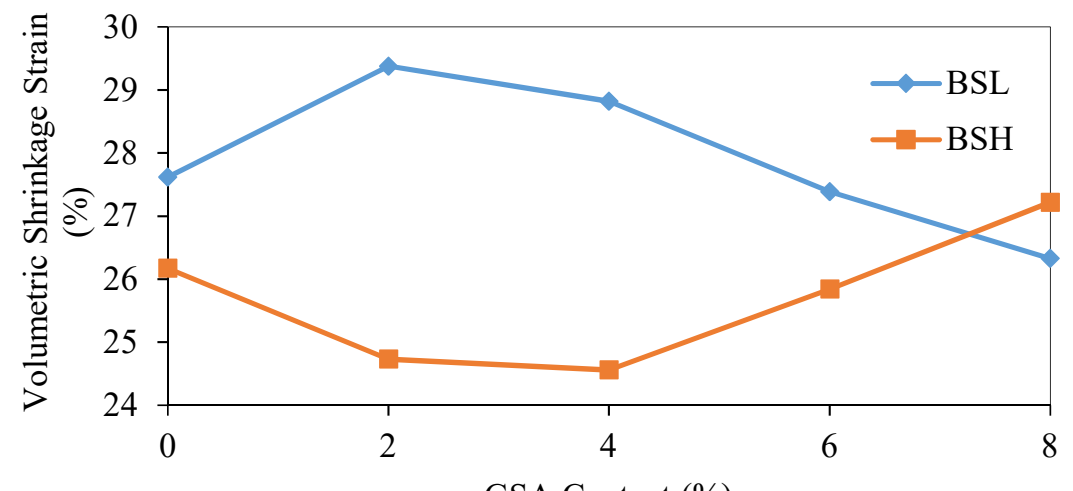

(a)

GSA Content (\%)

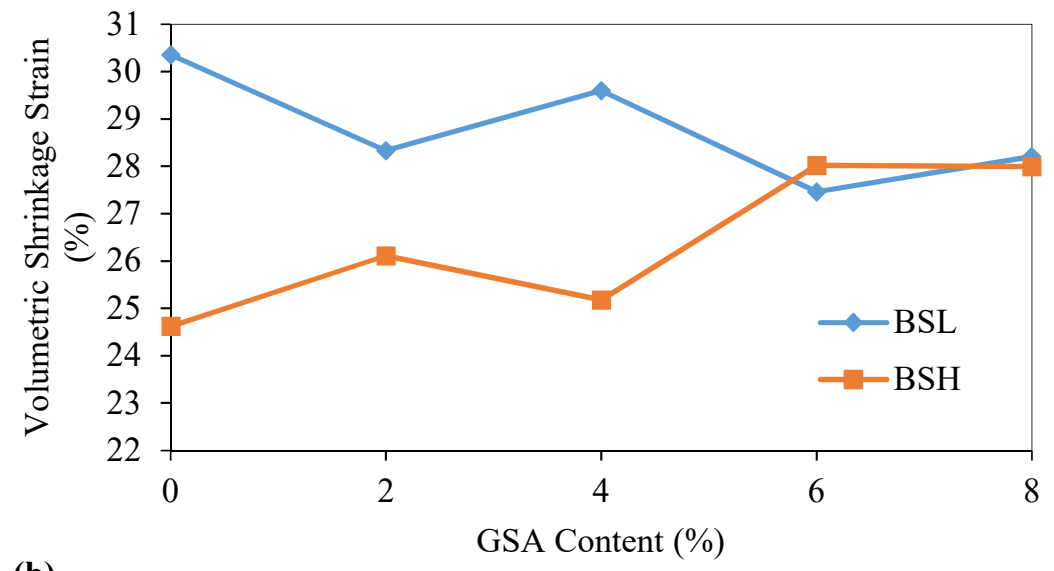

(b)

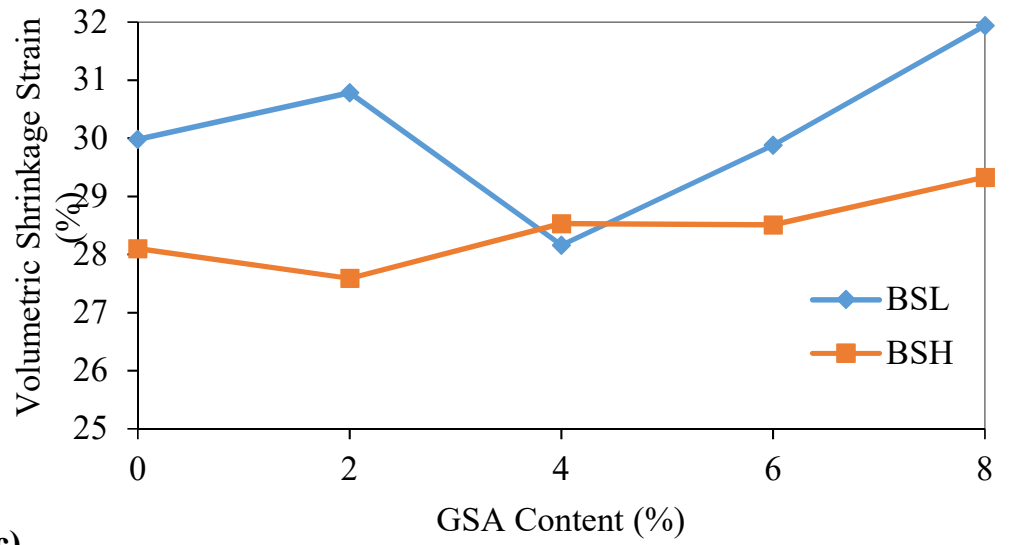

(c)

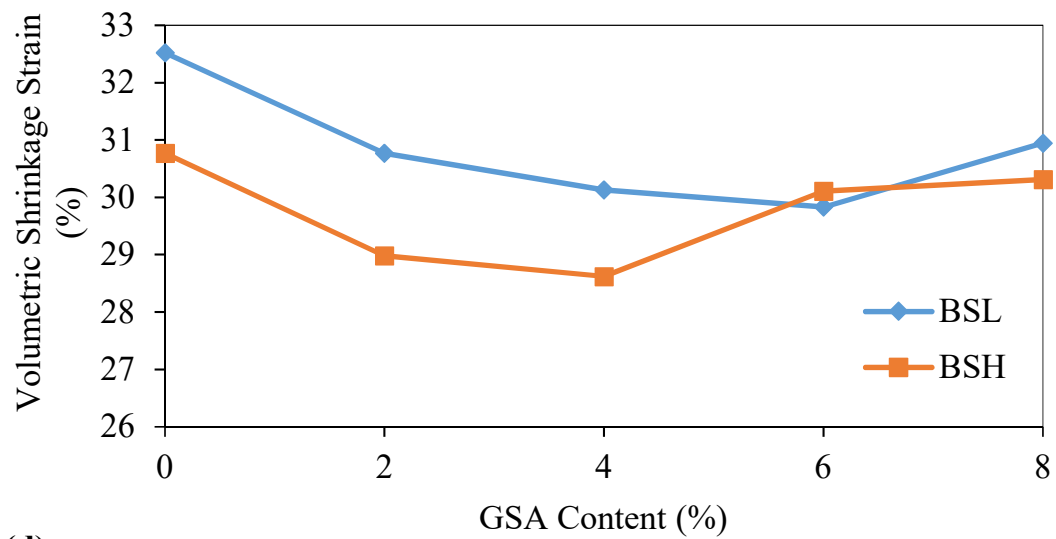

(d)

Figure 8. Variation of volumetric shrinkage strain with groundnut shell ash for (a) $-2 \%$ OMC (b) $0 \%$ OMC (c) $+2 \%$ OMC (d) $+4 \%$ OMC 


\subsection{Statistical analysis}

3.4.1 Regression analysis for volumetric shrinkage strain

Regression analysis in geotechnical engineering was reported by several researchers (Osinubi and Nwaiwu 2008; Bassey et al., 2017; Sani et al., 2017; Moses et al., 2018; Sani et al., 2019). Mini-tab R15 software and XLSTART 2014 statistical tool incorporated as an add-in in Microsoft Excel were used for the regression modelling and correlation analysis, respectively. The volumetric shrinkage strain (VSS) taken as dependent variable was expressed as a function of these independent variables; water content relative to optimum (WRO), groundnut shell ash content (GSA), plasticity index (PI), percentage fines, (PF) and compactive effort denoted by compactive effort index (CE). Therefore, based on multiple regression analysis, the VSS is expression is:

$V S S=24.128+0.608 W R O+0.147 G S A+0.096 P I+0.013 P F-0.93 C E$

where VSS, WRO, GSA, PI and PF are expressed in percentages and CE is an integer categorical variable where CE was assigned the values -1 and +1 for BSL and BSH compaction levels, respectively. Result of regression analysis show that all the parameters considered have effect on the volumetric shrinkage strain of the soil. The statistical parameters for the equation are given in Table 3. The coefficient of multiple determination, $\mathrm{R}^{2}$, for equation (2) is 0.731 , while the adjusted $\mathrm{R}^{2}$ value is 0.691 . The overall F-statistic (18.561) obtained is statistically significant at $95 \%$ confidence limit (i.e., $\alpha=0.05$ ). The p-value for compaction WRO as well as compactive effort were less than 0.05 . The coefficient of each parameter show the extent of the effect of the parameter on the volumetric shrinkage strain. WRO, GSA, PI and PF having positive coefficients depict the fact that increase in these parameters (WRO, GSA, PI and PF) will slide towards increase in volumetric shrinkage strain of the compacted soil. On the other hand CE having negative coefficients, depict decrease in VSS with increase in CE. Therefore, care should be taken to ensure these variables are properly managed and regulated at the site during ground compaction to accomplish a sustainable barrier system.

The line fit plot shows relationship between volumetric shrinkage strain (laboratory and predicted) of specimen with GSA content and WRO (see Fig 9 and 10). GSA content and compaction WRO variables were considered based on their higher coefficient compared to other variables in the VSS regression function. It is obvious from the fit line plot that the model yielded almost a perfect predicted values of VSS from measured laboratory values with most of the points (i.e. for predicted and measured values) having more or less unified point on the line fit plot (see Fig 9 and 10). The line fit plot were mostly observed to be overlapping each other.

The graphical plot of Fig. 11 provides the comparison of predicted and measured values of VSS. The predicted values from the regression model and measured laboratory result of volumetric shrinkage strains using a linear relationship, shows a strong relationship between predicted values and measured laboratory result having correlation coefficient $\mathrm{R}^{2}=0.731$ (see Fig 11).

Table 3. Results of multiple regression analysis for volumetric shrinkage strain

\begin{tabular}{|l|l|l|l|l|l|}
\hline Variables & Coefficients & Standard Error & t Stat & P-value & Regression parameters \\
\hline Intercept & 24.128 & 8.280 & 2.914 & 0.006 & $\mathrm{R}^{2}=0.73$ \\
\hline WRO & 0.608 & 0.078 & 7.747 & 0.000 & Adjusted $\mathrm{R}^{2}=0.69$ \\
\hline GSA & 0.147 & 0.122 & 1.198 & 0.239 & Standard Error $=1.109$ \\
\hline PI & 0.096 & 0.049 & 1.950 & 0.060 & Observations $=40$ \\
\hline PF & 0.013 & 0.105 & 0.122 & 0.904 & \\
\hline CE & -0.930 & 0.175 & -5.301 & 0.000 & \\
\hline
\end{tabular}

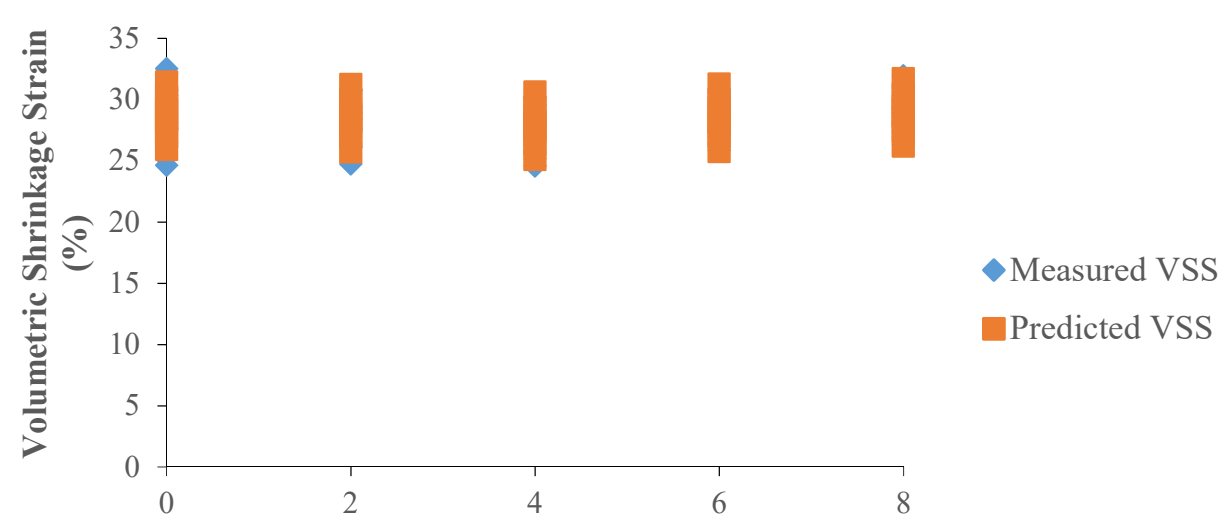

Groundnut Shell Ash content (\%)

Figure 9. Variation of volumetric shrinkage strain (Laboratory and predicted values) of soil with soil - groundnut shell ash mixture using line fit plot 


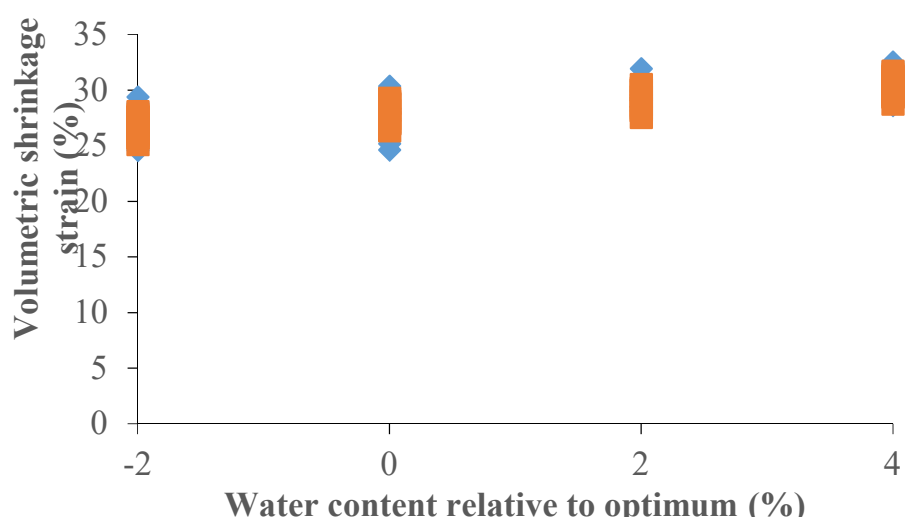

Measured VSS

Predicted VSS

Figure 10. Variation of volumetric shrinkage strain (Laboratory and predicted values) of soil - groundnut shell ash mixture with water content relative to optimum using line fit plot

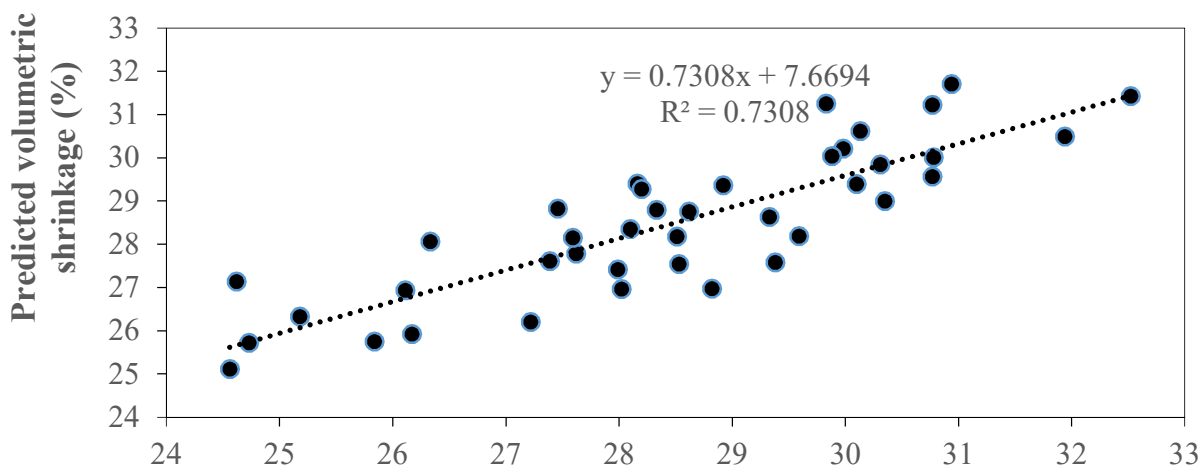

Measured volumetric shrinkage strain

Figure 11. Plot of predicted VSS values against measured VSS values of black cotton soil - GSA mixture. 3.4.2 Correlation analysis of volumetric shrinkage strain:

The correlation analysis for black cotton soil with VSS and the parameters related with VSS (WRO; GSA; PI and PF) reveals varying level of associations. The results of the correlation analysis are shown in Table 4-6. Positive correlation was observed between VSS and the associated parameters (WRO; GSA; PI and PF). The correlation coefficients, $R$, are relatively high $(R \geq 0.70)$ for volumetric shrinkage strain and compaction water content relative to optimum on one hand, having $\mathrm{p}$ values less than 0.05 . On the other hand, the R-value for VSS and GSA $(0.042$; $p \geq 0.05)$; PI (0.093; $p \geq 0.05)$; PF $(0.016 ; p \geq 0.05)$ disclosed a low values correlation. These variables (GSA, PI and $\mathrm{PF}$ ) could probably indicate low effect on the VSS values. The overall results of p-values and coefficient of determination $\left(\mathrm{R}^{2}\right)$ are shown in Tables 5 and 6 , respectively.

Table 4 Correlation matrix (Pearson) for volumetric shrinkage strain with associated parameters

\begin{tabular}{|l|l|l|l|l|l|}
\hline Variables & VSS & WRO & GSA & PI & PF \\
\hline VSS & 1 & & & & \\
\hline WRO & 0.703 & 1 & & & \\
\hline GSA & 0.042 & 0.524 & 1 & & \\
\hline PI & 0.093 & -0.360 & -0.719 & 1 & \\
\hline PF & 0.016 & 0.440 & 0.845 & -0.707 & 1 \\
\hline
\end{tabular}

Tables 5. P-values (Pearson) for volumetric shrinkage strain with associated parameters

\begin{tabular}{|l|l|l|l|l|l|}
\hline Variables & VSS & WRO & GSA & PI & PF \\
\hline VSS & 0 & & & & \\
\hline WRO & $<0.0001$ & 0 & & & \\
\hline GSA & 0.797 & 0.001 & 0 & & \\
\hline PI & 0.568 & 0.023 & $<0.0001$ & 0 & \\
\hline PF & 0.924 & 0.004 & $<0.0001$ & $<0.0001$ & 0 \\
\hline
\end{tabular}


Table 6. Coefficient of determination, $\mathrm{R}^{2}$ (Pearson) for volumetric shrinkage with associated parameters

\begin{tabular}{|l|l|l|l|l|l|}
\hline Variables & VSS & WRO & GSA & PI & PF \\
\hline VSS & $\mathbf{1}$ & & & & \\
\hline WRO & 0.495 & $\mathbf{1}$ & & & \\
\hline GSA & 0.002 & 0.274 & $\mathbf{1}$ & & \\
\hline PI & 0.009 & 0.129 & 0.516 & $\mathbf{1}$ & \\
\hline PF & 0.000 & 0.194 & 0.713 & 0.499 & $\mathbf{1}$ \\
\hline
\end{tabular}

$\mathrm{VSS}=$ volumetric shrinkage strain; WRO = water content relative to optimum; GSA = groundnut shell ash content; $\mathrm{PI}=$ plasticity index; $\mathrm{PF}=$ percentage fine content

\section{Conclusion}

Laboratory tests were conducted on black cotton soil treated with up to 8\% GSA content to assess desiccation effect on the compacted material for use as a hydraulic barrier in waste containment facility. The treated soil was compacted using British standard light (BSL) and British standard heavy (BSH) at moulding water contents of -2 , 0,2 and $4 \%$ of the respective optimums. Compacted samples were extruded from moulds and volumetric shrinkage strain (VSS) values were recorded at interval of 5 days up to 30 days of drying. The VSS decreased within the first five (5) days of drying and became constant by the 15th day. It was observed that VSS increased with higher moulding water and moulding water content relative to optimum, while it decreased with higher compaction effort. Volumetric shrinkage strain generally decreased with higher percentages of groundnut shell ash at all moulding water content regardless of the compaction effort used whilst none of its values fell within the acceptable range of less than or equal $4 \%$ for consideration in barrier formation. It has been established through this study that agro by-products (groundnut shell ash) can be considered as potential stabilizing agents to amend an expansive soil or to create a composite, which would reduce shrinkage and cracking. To realize this, a mathematical relationship between the volumetric shrinkage and related parameters (water content relative to optimum (WRO), groundnut shell ash content (GSA), plasticity index (PI), percentage fines, (PF) and compactive effort denoted by compactive effort index (CE)) was proposed. It is believed that this relationship would be quite useful for selecting different agro and or industrial by-products (with similar properties) for treating expansive soils to create a sustainable barrier. Based on the result of the study, it is recommended that the percentages of the GSA substitute be increased above $8 \%$ or be replaced or mixed with a more sustainable agro-based and or industrial material for the purpose of consideration as liners and covers of a barrier formation provided that VSS would be drastically minimize.

Funding No funding

Compliance with ethical standards

Conflict of interest. The authors declare that they have no conflict of interest.

\section{References}

AASHTO (1986): Standard Specification for transportation Materials and Methods of Sampling and Testing, 14th Edition. Am. Assoc. of State Hwy. and Transp. Officials, Washington, D.C.

Alabadan, B.A., M.A. Olutoye, M.S. Abolarin and M. Zakariya (2005) "Partial Replacement of Ordinary Portland Cement (OPC) with Bambara Groundnut Shell Ash (BGSA) in Concrete". Leonardo Electronic Journal of Practices and Technologies. Issue 6, pp.43-48, January-June 2005. Vol. 04.08, American Society for Testing and Material, Philadelphia.

Alabadan, B.A., Njoku, C. F. and Yusuf, M. O. (2006) "The Potentials of Groundnut Shell Ash as Concrete Admixture". Agricultural Engineering International: the CIGR E journal. Manuscript BC 05012 , Vol. VIII. February, 2006

Albrecht, B. A. and Benson, C. H. (2001) Effect of desiccation on compacted natural clay. J. Geotech \& Geoenvir. Engrg., ASCE, 127(1):67 - 75.

ASTM (1992) Annual book of ASTM standards, Vol. 04.08, 1992. Philadephia.

Bassey, O. B., Attah, I. C., Ambrose, E. E and Etim, R. K. (2017) Correlation between CBR Values and Index Properties of Soils: A Case Study of Ibiono, Oron and Onna in Akwa Ibom State. Resources and Environment, 7(4): 94-102. doi: 10.5923/j.re.20170704.02

Benson, C. H. Zhai, H. Wang, X. (1994) Estimating hydraulic conductivity of compacted clay liners. J. Geotech. Engrg. ASCE, 2: $366-387$.

British Standard Institute (1990), Methods of testing soils for civil engineering purposes. BS 1377, London.

British Standard Institute, Methods of tests for stabilized soils. BS 1924, 1990b. London.

Butcher, F.and Sailie, E. L. (1984) Swelling behaviour of tropical black clays. Proc. of the Eighth Reg. Conf. For Africa on Soil Mech. And Foundation Engineering, Harare, pp. 81-86

Coka, E. (2001) Use of class C fly ashes for the stabilization of an expansive soil. J. Geotech. Geoenviron Engr., $127(7): 568-573$. 
Daniel, D. E. and Benson, C. H. (1990) Water content density criteria for compacted soil liners. J. of Geotechnical Engrg. A.S.C.E, $116(12): 1811-1830$.

Daniel, D.E. (1993) Geotechnical Practice for Waste Disposal, Chapman and Hall, London, 1993

Daniel, D.E. and Wu, Y. K. (1993) Compacted clay liners and covers for arid site. J. Geotech. Engrg. ASCE, 119 (2) $223-237$.

Das, B.M. (1998). Principles of Geotechnical Engineering, 4th Edition,PWS publishing company,USA.

Eberemu, A. O. (2011). Desiccation Induced Shrinkage of Compacted Tropical Clay Treated with Rice Husk Ash. International Journal of Engineering Research in Africa, Vol. 6 (2011) pp 45-64. doi:10.4028/www.scientific.net/JERA.6.45

Eberemu, A.O., Amadi, A.A., Ibrahim, B. (2010) Diffusion of municipal waste contaminants in compacted lateritic soil treated with bagasse ash. Presented at the 1st West African International Workshop on landslides and other natural disasters, Nsukka 2010. March 22nd-26th. University of Nigeria Nsukka. Book of Abstract pp. 12.

Eberemu, O.A., Osinubi, K.J. (2010) Soil water characteristic curves of compacted lateritic soils treated with bagasse ash. In: Manoj Datta, Srivastava, R.K. Srivastava, G.V. Ramana, J.T. Shahu (eds.) Proceeding of the 6th International Congress on Environmental Geotechnics New Delhi, India. Nov. 8th-12th 2010. Environmental Geotechnics for Sustainable Development. Sessions on Testing and Monitoring. Tata McGraw Hill Education Private Limited Copyright, pp. 1378-1384

Etim, R. K., Eberemu, A. O. and Osinubi, K. J. (2014). Effect of lime - iron ore tailing blend on the expansive behavior of black cotton soil. Proceedings 2014 Nigerian Engineering Conference, Theme: Engineering and Technology for Economic Transformation. Ahmadu Bello University Zaria. 15th - 18th Sept. 2014, Zaria, Kaduna State. CD ROM of Presentation. Section 6. Pg. $864-872$.

Etim, R.K., Eberemu, A.O., and Osinubi, K.J. (2017). Stabilization of black cotton soil with lime iron ore tailings admixture. Transportation Geotechnics. Elsevier, 10: 85 - 95.

Ferguson, G. (1993) Use of self-cementing fly ashes as a soil stabilization agent. Fly ash for soil improvement, Geotechnical special publication No. 36, ASCE, 1-14.

Haines, W., 1923. The volume-changes associated with variations of water content in soil. J. Agric. Sci., 13:296310.

Ijimdiyaa, T.S., Ashimiyu, A.L. Abubakar, D.K. (2012) Stabilization of Black Cotton Soil Using Groundnut Shell Ash. Electonic Journal of Geotechnical Engineering (EJGE). Vol 17: Bund Y. 3645-3652.

Jayanthi, P. N. V. Kuntikana, G. and Singh, D. N. (2017) Stabilization of Fine-Grained Soils against Desiccation Cracking Using Sustainable Materials. Advances in Civil Engineering Materials, Vol. 6 / No. 1: 35-67. https://doi.org/10.1520/ACEM20160037

Liman, A. (2009). "Evaluation Compacted Lateritic Soil Treated With Cement Kiln Dust as Hydraulic Barriers in Municipal Solid Waste Containment Systems." Unpublished MSc Thesis, Department of Civil Engineering, Ahmadu Bello Univesity, Zaria.

Mitchel, K.J. (2008) Performance of engineered waste containment barriers. Geotechnics of waste management and remediation. Geotechnical Special Publication. ASCE. Geocongress 2008. GSP 177, pp 1-15.

Mitchell, J. K. (1976) Fundamental of Soil Behaviour. John Wiley and Sons, Inc. New York.

Moses, G. Peter, O. F. O. and Osinubi, K. J. (2016) Desiccation-induced volumetric shrinkage of compacted metakaolin-treated black cotton soil for a hydraulic barriers system. Slovak Journal of Civil Engineering, Vol. 24, 2016, No. 1, 1 - 5. DOI: 10.1515/sjce-2016-0001

Moses, G., Etim, R.K., Sani, J. E., Nwude, M. (2018) Desiccation effect of compacted tropical black clay treated with concrete waste. Leonardo Electronic Journal of Practices and Technologies, Issue 33: p. 69-88

Nicholson, P.G. and Kashyap, V. (1993) Flyash stabilization of tropical Hawaiian soils. Fly ash for soil improvement, Geotechnical special publication, ASCE 36: 15-29.

Osinubi, K.J. and Eberemu, A. O, (2009) Desiccation- Induced Shrinkage of Compacted Lateritic Soil Treated with Bagasse Ash. The Twenty Fourth International Conference of Solid Waste Technology and Management CD-ROM, 15th-18th March 2009, Philadelphia, PA. USA. Session 5c; Bioreactors and Innovative Landfills, $856-867$.

Osinubi, K.J. and Eberemu, A. O. (2010) Desiccation induced shrinkage of compacted lateritic soil treated with blast furnaces slag. Geotech Geol Engr Journal, 28:537 - 547.

Osinubi, K. J. and Amadi, A. A. (2009). "Hydraulic Performance of Compacted Lateritic Soil Bentonite Mixtures Permeated with Municippal Solid Waste Landfill Leachete.” Transportation Reseach Board (TRB) 88 Annual Meeting CD-ROM 11-15 January, Washington DC, U.S.A. Subject. Geology and Earth Materials, Session APP40-Physico-Chemical and Biological Process in Soils Committe, Paper 4090620, pp 1-18.

Osinubi, K. J. and Eberemu, A. O. (2006). "Hydraulic conductivity of lateritic soils treated with blast furnace slag." Electronic Journal of Geotechnical Engineering. EJGE, Vol. 11. Bundle D, pp. $1-21$.

Osinubi, K. J. and Nwaiwu, C. M. (2005). "Hydraulic conductivity of compacted lateritic soils." Journal of 
Geotechnical and Geoenvironmental Engineering, ASCE, Vol. 131, No. 8, pp. $1034-1041$.

Osinubi, K. J., and Amadi, A. A. (2010). 'Comparative assessment of contaminant sorption in lateritc soil bentonite mixtures.' Geoenvironmental Processes for Soil Remediation and Geohazard Mitigation, CD-ROM Geotechnical Special Publication No. 199, pp. 2779 - 2786.

Osinubi, K. J., Yohanna, P. and Eberemu, A. O. (2015) "Cement modification of Tropical Black clay using Iron Ore Tailing as Admixture.” Journal of transportation Geotechnics 5: 35-49.

Osinubi, K.J. and Nwaiwu, C. M. O. (2002) Compacted lateritic soils as hydraulic barriers in waste containment systems. Proc. 4th International Congress on Environmental Geotechnics.(ICEG), Rio de Janeiro, Brazil, 11 - 15 August, 225-230.

Osinubi, K.J., Eberemu, A. O. and Amadi, A. A. (2009) Compacted lateritic soil treated with blast furnaces slag as hydraulic barriers in waste containment. Int. J. Risk Assessment and Management, 13 (2):177 - 188.

Osinubi, K.J., Eberemu, A. O. and Kasham, L.S. (2007) Influence of bagasse ash content on the hydraulic conductivity of compacted lateritic soils at reduced Proctor effort. Proceedings of Bi-Monthly Meetings/Workshops. Materials Society of Nigeria (MSN) Zaria Chapter. A.B.U. Zaria. 17 - 25.

Osinubi, K.J., Eberemu, A.O., Amadi A.A.(2009) Compacted lateritic soil treated with blast furnaces slag as hydraulic barriers in waste containment. Int. J. Risk Assess. Manag. 13(2), 171-188.

Pandian, N. and Krishma, K. (2003) The pozzolanic effect of fly ash on the California bearing ratio behaviour of black cotton soil. J. Testing and Evaluation, ASTM, 31 (6):479 - 485.

Rowe, R. K., Quigley, M. R. and Booker, R. J. (1995) Clayey Barrier Systems for Waste Disposal facilities. E \& FN Spon. An imprint of Chapman \& Hall, London. 1995.

Sani, J. E., Yohanna, P., Etim K. R., Osinubi, J. K. and Eberemu, O. A. (2017) Reliability Evaluation of Optimum Moisture Content of Tropical Black Clay Treated with Locust Bean Waste Ash as Road Pavement Sub-base Material. Geotech Geol Eng, 35:2421-2431. DOI 10.1007/s10706-017-0256-2

Sani, J. E., Etim, R.K. Joseph, A. (2019) Compaction Behaviour of Lateritic Soil-Calcium Chloride Mixtures. Geotechnical and Geological Engineering. Springer Nature Switzerland. 37:2343-2362. https://doi.org/10.1007/s10706-018-00760-6

Taha, O.M.E and Taha, M.R. (2011) Cracks in Soils Related to Desiccation and Treatment, Australian Journal of Basic and Applied Sciences, 5(8): 1080-1089.

Terzi, N. U. (2009) Influence of fly ash and cement on the Consolidation and Strength Properties of Expansive very soft Halic Mud. The Twenty - Fourth International Conference on Solid Waste Technology and Management CD-ROM, 15 - 18 March,Philadelphia, PA, U.S.A. Session 5C: Bioreactors and Innovative Landfills, 1523-1533.

Trzebiatowski, B. Edil, T. and Benson, C. (2004) Case study of subgrade stabilization using flyash: State Highway 32. Recycled Materials in geotechs, GSP No. 127, A. Aydilek and J. Wartman, eds, ASCE, Reston, Va, 123136.

U.S. EPA (2009) "Inventory of U.S. Greenhouse Gas Emissions and Sinks: 1990 - 2007. EPA 430-R-09-004." U.S. Environmental Protection Agency, Washington D.C. 20460. 